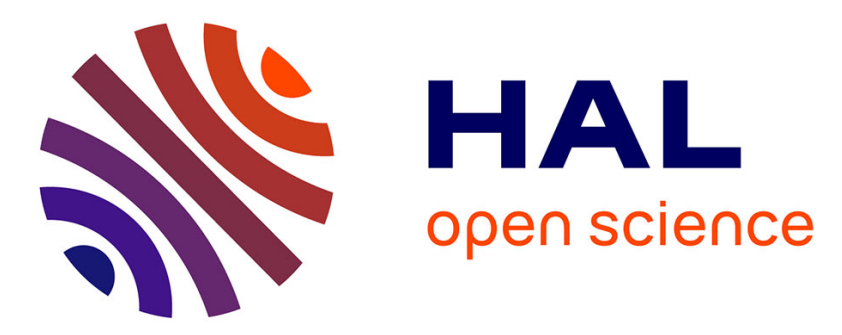

\title{
3D model related to the publication: First record of the family Protocetidae in the Lutetian of Senegal (West Africa)
}

Lionel Hautier, Raphaël Sarr, Fabrice Lihoreau, Rodolphe Tabuce, Pierre Marwan Hameh

\section{To cite this version:}

Lionel Hautier, Raphaël Sarr, Fabrice Lihoreau, Rodolphe Tabuce, Pierre Marwan Hameh. 3D model related to the publication: First record of the family Protocetidae in the Lutetian of Senegal (West Africa). MorphoMuseum, 2015, 1 (1), pp.e2. 10.18563/m3.1.1.e2 . hal-01923074

\section{HAL Id: hal-01923074 https://hal.science/hal-01923074}

Submitted on 9 Nov 2020

HAL is a multi-disciplinary open access archive for the deposit and dissemination of scientific research documents, whether they are published or not. The documents may come from teaching and research institutions in France or abroad, or from public or private research centers.
L'archive ouverte pluridisciplinaire $\mathbf{H A L}$, est destinée au dépôt et à la diffusion de documents scientifiques de niveau recherche, publiés ou non, émanant des établissements d'enseignement et de recherche français ou étrangers, des laboratoires publics ou privés. 


\title{
3D model related to the publication: First record of the family Protocetidae in the Lutetian of Senegal (West Africa)
}

\author{
HAUTIER L. ${ }^{a *}$, SARR R. ${ }^{b}$, LIHOREAU F. ${ }^{a}$ TABUCE R. ${ }^{a}$ and MARWAN HAMEH P. ${ }^{c}$ \\ a Laboratoire de Paléontologie, Institut des Sciences de l'Évolution de Montpellier (ISE-M, UMR 5554, CNRS, UM2, IRD), c.c. \\ 064, Université Montpellier 2, place Eugène Bataillon, F-34095 Montpellier Cedex 05, France \\ b Département de Géologie, Faculté des Sciences et Techniques, Université Cheikh-Anta-Diop de Dakar, B. P. 5005 Dakar-Fann, \\ Sénégal \\ c COGITECH, B.P. A362 Thiès, Senegal \\ * corresponding author: Lionel.Hautier@univ-montp2.fr
}

\begin{abstract}
This contribution contains the 3D model described and figured in the following publication: Hautier L, Sarr R, Lihoreau F, Tabuce R, Marwan Hameh P. 2014. First record of the family Protocetidae in the Lutetian of Senegal (West Africa). Palaeovertebrata 38 (2)-e2
\end{abstract}

Key words: Innominate, Protocetid, Senegal

Submitted 14.11.2014, Accepted 04.12.2014. doi: 10.18563/m3.1.1.e2

(C) Copyright Lionel Hautier December 2014

\section{TECHNICAL AND SPECIMEN-RELATED PARAMETERS}

\begin{tabular}{|l|l|}
\hline Specimen number & SN103 \\
\hline Species & Protocetid indet. \\
\hline Repository institution & University Cheikh Anta Diop, Dakar, Senegal \\
\hline 3D data acquisition institution & ISE-M, Université Montpellier 2 \\
\hline 3D data acquisition method & X-ray $\mu$ CT \\
\hline 3D data acquisition facility model & In Vivo Mictotomograph SkyScan 1076 \\
\hline 3D data acquisition operator & Renaud Lebrun (ISE-M) \\
\hline Voxel size of original dataset & 0,072 mm \\
\hline Author of derived 3D surface model & Lionel Hautier \\
\hline Model ID & M3\#5 SN103 \\
\hline
\end{tabular}

\section{METHODS}

The innominate was extracted within a "labelfield" module of AVIZO 7.1 (Visualization Sciences Group), using the segmentation threshold selection tool. The $3 \mathrm{D}$ model is provided in .ply format, and as such can be opened with a wide range of freeware. Additional files specific to ISE-MeshTools (Lebrun, 2014) are provided in order to visualize the innominate in standard orientation.

\section{ACKNOWLEDGEMENTS}

Data presented in this work were produced through the technical facilities of the MRI platform and of the labEx CeMEB. This is ISE-M contribution 2014-222 S.

\section{BIBLIOGRAPHY}

Hautier L, Sarr R, Lihoreau F, Tabuce R, Marwan Hameh P. 2014. First record of the family Protocetidae in the Lutetian of Senegal (West Africa). Palaeovertebrata 38(2)-e2

Lebrun, R., 2014. ISE-MeshTools, a 3D interactive fossil reconstruction freeware. 12th Annual Meeting of EAVP, Torino, Italy. 